\title{
Effect of Carbon-Nitrogen Ratios of Lignocellulosic Substrates on the Yield of Mushroom (Pleurotus pulmonarius)
}

\author{
Michael Omofowa Osunde1, Akinyemi Olayinka1, Christina Dunah Fashina², Nkem Torimiro² \\ ${ }^{1}$ Department of Soil Science and Land Resources Management, OAU, Ile-Ife, Nigeria \\ ${ }^{2}$ Department of Microbiology, OAU, Ile-Ife, Nigeria \\ Email: mikeosund2016@yahoo.com
}

How to cite this paper: Osunde, M.O., Olayinka, A., Fashina, C.D. and Torimiro, N. (2019) Effect of Carbon-Nitrogen Ratios of Lignocellulosic Substrates on the Yield of Mushroom (Pleurotus pulmonarius). Open Access Library Journal, 6: e5777.

https://doi.org/10.4236/oalib.1105777

Received: September 9, 2019

Accepted: October 18, 2019

Published: October 21, 2019

Copyright $\odot 2019$ by author(s) and Open Access Library Inc.

This work is licensed under the Creative Commons Attribution International License (CC BY 4.0).

http://creativecommons.org/licenses/by/4.0/

\begin{abstract}
Mushrooms are fungi that are unique in the recycling of plant biomass through decomposition in the process of which they also serve as food for man. These functions are carried out through the extracellular digestion of plant biomass with a consortium of enzymes. This study examined the effect of carbon-nitrogen ratios $(\mathrm{C} / \mathrm{N})$ of three lignocellulosic substrates, namely, corncob (C/N 120:1), sawdust (C/N 325:1) and waste paper (C/N 400:1) on the yield of Pleurotus pulmonarius. The experimental design was factorial laid out in Randomized Complete Block Design (RCBD). Tissue culture was made on Potato Dextrose Agar (PDA) which was transferred to boiled sorghum grains for spawn making. The substrates were pasteurized and then inoculated with $P$. pulmonarius. Substrates were pasteurized (immersed in hot water for 3 hours) and inoculated with $P$. pulmonarius. Proximate analysis of the fruiting bodies was done to determine crude protein, crude fat, moisture content, dry matter, ash, crude fiber and carbohydrate. Carbon-nitrogen $(\mathrm{C} / \mathrm{N})$ ratio of the substrates was also determined. Corncob has $\mathrm{C} / \mathrm{N}$ ratio of $120: 1$. The yield performance of corncob was the highest for weight $(86 \pm 0.01$ g), length of stipe $(3.55 \pm 0.04 \mathrm{~cm})$ and diameter of pileus $(7.3 \pm 0.07 \mathrm{~cm})$. Means separation by least significant difference (LSD) showed that the yield parameters for corncob were statistically different from other substrates used. The proximate analysis of dried $P$. pulmonarius showed that corncob had a protein content of $17.37 \% \pm 0.80 \%$ and moisture content of $0.69 \% \pm 0.01 \%$ respectively, while sawdust and corncob had crude fibre contents of $1.79 \pm$ 0.02 and $1.79 \pm 0.01$ respectively. Conclusively, having an idea of the carbon-nitrogen ratio of the substrate to be used for mushroom cultivation, manipulating the nutritional composition of mushrooms can be enhanced by enriching the growth substrates/media.
\end{abstract}




\section{Subject Areas}

Biochemistry

\section{Keywords}

Lignocellulosic Substrates

\section{Introduction}

Pleurotus pulmonarius is a fungus known to degrade complex lignin-cellulose-hemicellulose structure and take up nutrients for its development. It grows on a wide range of woody materials such as agricultural wastes and forestry, which are mainly composed of polymers found in the cell walls of the plant cells, such as cellulose $(40 \%-60 \%)$, hemicellulose $(15 \%-35 \%)$ and lignin $(10 \%-30 \%)$ which are the main source of carbon (C) and nitrogen $\left(\mathrm{N}_{2}\right)$ [1]. The fungus is able to achieve this feat with its enzymes which could either be constitutive or inductive in nature. Apart from breakdown of lignocellulosic plant biomass, immobile nutrients are also made available to plants through the process of mineralization [2]. This unique recycling capability makes mushroom a special mop for plant biomass while providing food for man. Lignocellulosic bases are of great importance in mushroom diets as they form the skeletal frame work upon which other nutrients are built [1]. Mushrooms have been used to exploit the natural ability of fungi to bio-divert solid waste generated by industry and agriculture into food and therefore many agricultural and industrial wastes can be utilized as substrates for production of Pleurotus species [3] [4]. Corncob is a major agricultural waste in Nigeria that is rich in lignocellulosic content but utilization for energy generation or bioconversion is low. The situation is the same for waste paper and sawdust. Nitrogen is a major constituent of amino acids which in turn are the precursors for proteins. Since the mode of nutrition of mushroom is by assimilation [5], increased protein level of fruiting bodies can be achieved by using substrates rich in nitrogen and low in carbon contents. The aim of this study was to examine the yield and the nutritional composition of the fungus, Pleurotus pulmonarius.

\section{Materials and Methods}

The study was a factorial experiment laid out in Randomized Complete Block Design (RCBD) with treatments in triplicates. Corncob was collected from the Teaching and Research Farm of Obafemi Awolowo University, Ile-Ife, sawdust was collected from a sawmill along Ondo road, Ile-Ife while waste paper was obtained from newspaper vendor on OAU, campus, Ile-Ife. Pleurotus pulmonarius was obtained at the Department of Crop Production and Protection, Faculty of Agriculture, OAU, Ile-Ife. 


\subsection{Tissue Culture and Spawn Preparation}

Thin sections of the mushroom's pileus were cut and aseptically transferred to a PDA plate and incubated at $28^{\circ} \mathrm{C}$ for complete colonization. Spawns were prepared by cutting mycelia from the agar culture and aseptically transferring the section into bottles containing sterilized sorghum grains and incubated at $28^{\circ} \mathrm{C}$ for complete ramification.

\subsection{Preparation of Substrates and Inoculation}

Corncob and waste paper chopped and shredded into smaller sizes respectively. $800 \mathrm{~g}$ of each substrate used was treated with a mixture of hot water and calcium carbonates (1.5\% of the substrate used) for 1 hour and was drained overnight. Aseptically, $25 \mathrm{~g}$ of spawn was transferred to $200 \mathrm{~g}$ of each substrate used and incubated at $28^{\circ} \mathrm{C}$ for complete ramification.

\subsection{Harvesting of Fruiting Bodies and Proximate Analysis Determination}

Matured fruiting bodies were harvested in two flushes (harvesting period), dried and analyzed according to [6] to determine crude protein, crude fat, moisture contents, dry matter, ash, crude fiber and carbohydrate. The total nitrogen and carbon content were also determined according to [6].

\section{Statistical Analyses}

All data were subjected to analyses of variance (ANOVA) to detect significant differences among substrates and flushes. Variation among substrates was further separated using least significant difference (LSD)at a probability level of 0.05. All analyses were performed using Statistical Analysis System (SAS) version $9.1[7]$.

\section{Results and Discussion}

The result on Table 1 shows that corncob had the highest yield for flushes 1 and 2 of $86 \pm 0.01 \mathrm{~g}$ and $53 \pm 0.71 \mathrm{~g}$ respectively. The differences in yield amongst substrates may be due to differences in substrate's porosity and water holding capacity. [8] asserts that the productivity of the different substrates is dependent on the water holding capacity as well as porosity of the substrates which allows for efficient respiration of mycelia and easy access for enzymes to the nutrients present in them, thus resulting in better mycelial development. The differences in yield may also be due to the presence of less complex carbohydrates and other growth factors. This may be attributed to the presence of less phenolic compounds in corncob which may enhance the rapid growth of mycelia due to less toxicity as against the yield from sawdust. [9] and [10] reported that phytoanticipin and phytoalexins are responsible for reduced fungal growth since they exist as remote preformed precursors in response to pathogen attack.

Table 1 also shows that there were significant differences in the length of stipe 
and the diameter of the pileus of the mushroom obtained from the different substrates used. Corncob was significantly different both in the length of the stipe and the diameter of the pileus and this can be supported by the findings of [11] who reported that substrate types influence the length of the stipe as well as the diameter of the pileus.

\section{Carbon-Nitrogen Ratio}

The result shows that the carbon-nitrogen $\operatorname{ratios}(\mathrm{C} / \mathrm{N})$ for sawdust and waste paper was as high as 325 and 400 , respectively. The $\mathrm{C} / \mathrm{N}$ ratio for corncob was relatively low (120) when compared with other substrates used as shown in Table 2. The improved growth and high yield obtained from corncob is due to higher nitrogen content and a lowered $\mathrm{C} / \mathrm{N}$ ratio. This yield difference obtained from corncob may be due to higher amount of nitrogen readily available for the biosynthesis of purines and pyrimidines needed for amino acids synthesis which are the building blocks of cellular proteins [12]. Studies by [13] have shown that pentose sugars were the most abundant in corncob prior of pretreatment. This also compliments the available nitrogen present in corncob for rapid growth of mushroom. Purines and pyrimidine's nitrogenous bases are the bases upon which pentose sugars are built thus making it easy for the mushrooms to build up much cellular biomass compared to those cultivated on waste paper and sawdust that are highly rich in lignin. The lignin content of a substrate affects its utilization by organisms that use it as source of energy. The presence of high amount of lignin in sawdust may also have contributed to the low yield of sawdust due to its resistance to degradation by the enzymes produced by $P$. pulmonarius. [14] reported that lignin content of substrates affects the overall yield due to low degradation of substrate by enzymes secreted.

Table 3 shows that for all the parameters measured, there existed significant

Table 1. Yield performances on different substrates of $P$. pulmonarius.

\begin{tabular}{ccccc}
\hline & Substrate & $\mathrm{W}(\mathrm{g})$ & Length of stipe $(\mathrm{cm})$ & Diameter of pileus $(\mathrm{cm})$ \\
\hline \multirow{3}{*}{ Flush 1 } & Waste paper & $79 \pm 0.71^{\mathrm{b}}$ & $3.15 \pm 0.11^{\mathrm{b}}$ & $6.15 \pm 0.11^{\mathrm{b}}$ \\
& Sawdust & $71.5 \pm 1.06^{\mathrm{c}}$ & $3.05 \pm 0.04^{\mathrm{b}}$ & $7.05 \pm 0.04^{\mathrm{a}}$ \\
& corncob & $86 \pm 0.01^{\mathrm{a}}$ & $3.55 \pm 0.04^{\mathrm{a}}$ & $7.3 \pm 0.07^{\mathrm{a}}$ \\
\multirow{2}{*}{ Flush 2 } & Waste paper & $49.5 \pm 1.06^{\mathrm{b}}$ & $2.8 \pm 0.07^{\mathrm{a}}$ & $5.5 \pm 0.07^{\mathrm{b}}$ \\
& Sawdust & $42 \pm 1.41^{\mathrm{c}}$ & $2.85 \pm 0.04^{\mathrm{a}}$ & $5.5 \pm 0.07^{\mathrm{b}}$ \\
& corncob & $53 \pm 0.71^{\mathrm{a}}$ & $2.85 \pm 0.04^{\mathrm{a}}$ & $6 \pm 00.1^{\mathrm{a}}$ \\
\hline
\end{tabular}

Means carrying the same alphabets are not significantly different; ${ }^{*}$ Comparison in a row.

Table 2. Carbon-nitrogen ratios of the different substrates.

\begin{tabular}{cccc}
\hline Substrates & Carbon $(\%)$ & Nitrogen $(\%)$ & C/N ratio \\
\hline Corncob & 72 & 0.6 & 120.0 \\
Paper waste & 40 & 0.1 & 400.0 \\
Sawdust & 32.5 & 0.1 & 325.0
\end{tabular}


Table 3. Mean Squares for Substrates, Flushes and their Interaction on P. Pulmonarius growth.

\begin{tabular}{ccccc}
\hline Source & DF & Weight $(\mathrm{g})$ & Stipe $(\mathrm{cm})$ & Pileus $(\mathrm{cm})$ \\
\hline Rep & 2 & 0.667 & 0.008 & 0.0 \\
Flushes & 1 & $4232.000^{\star *}$ & $0.911^{\star *}$ & $6.125^{\star *}$ \\
Substrate & 2 & $246.375^{\star *}$ & $0.091^{\star}$ & $1.024^{\star *}$ \\
Substrate Vs. Flushes & 2 & 6.125 & $0.071^{\star}$ & $0.324^{\star *}$ \\
Error & 4 & 2.625 & 0.007 & 0.003 \\
R-Square (\%) & & 99.779 & 98.027 & 99.867 \\
CV (\%) & & 2.551 & 2.670 & 0.864 \\
\hline
\end{tabular}

*, ** Significant at the 0.05 and 0.01 probability level, respectively.

differences for the weight of mushrooms obtained from flushes and the different substrates used. The yields of the mushroom were significantly affected by the substrate types and period of flushes. The performances in the first flush were significantly higher than those of the second. This can be attributed to the depletion of nutrients in the second flush. The outcomes obtained from the flushes in this study are similar to the findings of [15] that had higher yield in first flush compared to the second flush.

The LSD mean separation of the different substrates showed that the weight of mushroom obtained from corncob had the highest performance when compared to the two other substrates used in this study. It also showed that the stipe and pileus of the mushroom harvested from corncob were significantly different from those obtained from waste paper and sawdust. These differences in mushroom's parameters may be due to the fact that both waste paper and sawdust are richer in lignocellulosic materials when compared to corncob. The stipe of mushrooms harvested from waste paper and sawdust were not significantly different from each other but there exists a significant difference in the pileus harvested from waste paper and sawdust as shown in Table 4. In all of the parameters examined, corncob was significantly different from other substrates used.

Table 5 shows the mean separation on the flushes shows that there was no significant difference in the three parameters studied under both flushes. But the parameters on flush 1 were significantly different from those of flush 2 . The higher performance in flush 1 may be due to the higher concentrations in the amount of sugars present in the substrate at the start. Significant quantities of the simple sugars will have been taken up leaving behind lignocellulosic materials which may require more energy from the mycelial to hydrolyse to produce sugars that would be assimilated by the mushroom [16].

The proximate analysis of the fruiting bodies harvested showed that the fruiting bodies harvested from corncob had the highest protein, moisture and ash contents. Sawdust had the highest fat content, crude fibre and dry matter per 100 g sample used. The finding of this study with regards to the protein content of fruiting bodies of mushroom harvested from sawdust is in agreement with the 
Table 4. LSD Mean Values of growth parameters as affected by type of substrate.

\begin{tabular}{cccc}
\hline & Waste paper & Sawdust & Corncob \\
\hline Weight & $64.25^{\mathrm{b}}$ & $56.75^{\mathrm{c}}$ & $69.50^{\mathrm{a}}$ \\
Stipe & $2.96^{\mathrm{b}}$ & $3.00^{\mathrm{b}}$ & $3.20^{\mathrm{a}}$ \\
Pileus & $5.83^{\mathrm{c}}$ & $6.28^{\mathrm{b}}$ & $6.65^{\mathrm{a}}$ \\
\hline
\end{tabular}

LSD weigh $(0.05)=2.0515$, LSD stipe $(0.05)=0.1785$, LSD pileus $(0.05)=0.3202 ;{ }^{*}$ Comparison in a row Means carrying the same alphabets are not significantly different.

Table 5. Mean values for parameters as influenced by flush.

\begin{tabular}{cccc}
\hline & Weight & Stipe & Pileus \\
\hline Flush 1 & $78.833^{\mathrm{a}}$ & $3.283^{\mathrm{a}}$ & $6.833^{\mathrm{a}}$ \\
Flush 2 & $48.167^{\mathrm{b}}$ & $2.833^{\mathrm{b}}$ & $5.667^{\mathrm{b}}$ \\
\hline
\end{tabular}

LSD weigh $(0.05)=1.6751$, LSD stipe $(0.05)=0.1458$, LSD pileus $(0.05)=0.2614 ;{ }^{*}$ Means carrying the same alphabets are not significantly different

Table 6. Proximate analysis of mushroom as affected by substrate.

\begin{tabular}{cccccccc}
\hline Sample Type & Protein (\%) & Moisture (\%) & Fat (\%) & Ash (\%) & Crude fibre (\%) & Carbohydrate (\%) & g/100g dry matter \\
\hline Waste paper & $12.1 \pm 0.071$ & $0.82 \pm 0.03$ & $0.19 \pm 0.01$ & $2.29 \pm 0.06$ & $1.79 \pm 0.01$ & $82.81 \pm 0.05$ & $99.18 \pm 0.03$ \\
Corncob & $17.37 \pm 0.80$ & $0.69 \pm 0.02$ & $0.17 \pm 0.01$ & $2.2 \pm 0.01$ & $1.79 \pm 0.02$ & $79.93 \pm 0.82$ & $99.29 \pm 0.04$ \\
Sawdust & $14.2 \pm 0.28$ & $0.83 \pm 0.01$ & $0.16 \pm 0.01$ & $2.38 \pm 0.01$ & $1.77 \pm 0.01$ & $80.67 \pm 0.3$ & $99.17 \pm 0.01$ \\
\hline
\end{tabular}

finding of [17] with a range of protein content of different species of Macrocybe crassa cultivated on sawdust between $11.85 \%$ to $26.10 \%$. Table 6 shows that consequently, the $\mathrm{N}$ contents of the substrates used affected the nutrient content of the final fruiting bodies.

\section{Conclusion}

This study showed that the yields and nutrient contents of mushroom can be increased by using substrates rich in the nutrient of interest or by enriching the substrates through the addition of desired components. Having an idea of the carbon-nitrogen ratio of the substrate to be used for mushroom cultivation, manipulating the final composition of mushrooms can be enhanced by enriching the growth substrates. The technology of augmenting the nutritional composition of substrate may further increase the protein content of mushroom which may be used as a substitute for animal proteins and reduce dependence on animals for dietary protein.

\section{Conflicts of Interest}

The authors declare no conflicts of interest regarding the publication of this paper. 


\section{References}

[1] Cueva, M.B.R., Hernández, A. and Niño-Ruiz, Z. (2017) Influence of C/N Ratio on Productivity and the Protein Contents of Pleurotus ostreatus Grown in Different Residue Mixtures. Revista de la Facultad de Ciencias Agrarias, 49, 331-344.

[2] Hillel, D., Reosenzweig, C., Powlson, D., Scow, K., Singer, M. and Sparks, D. (2008) Nitrogen in Soil. In: Encyclopedia of Soils in the Environment, Academic Press, Cambridge, Vol. 3, 13-55.

[3] Zadrazil, F. and Brunnert, F. (1981) Investigation of Physical Parameters Important for the Solid-State Fermentation of Straw by White Rot Fungi. European Journal of Applied Microbiology and Biotechnology, 11, 183-188. https://doi.org/10.1007/BF00511259

[4] Oseni, T.O., Dube, S.S., Wahome, P.K., Masarirambil, M.T. and Earnshaw, D.M. (2012) Effect of Wheat Bran Supplement on Growth and Yield of Oyster Mushroom (Pleurotus ostreatus) on Fermented Pine Sawdust Substrate. Experimental Agriculture \& Horticulture, 12, 30-40.

[5] Ghosal, D., Ghosh, S., Dutta, T.K. and Ahn, Y. (2016) Current State of Knowledge in Microbial Degradation of Polycyclic Aromatic Hydrocarbons (PAHs). Frontiers in Microbiology, 7, 1369. https://doi.org/10.3389/fmicb.2016.01369

[6] AOAC (1995) Official Methods of Analysis. 16th Edition, Association of Official Analytical Chemists, Arlington.

[7] SAS Institute (2001) Statistical Analysis Software (SAS) User's Guide. SAS Institute, Inc., Cary.

[8] Zaghi, J.L.L., Linde, G.A. and Colauto, N.B. (2010) Carbon-to-Nitrogen Ratios for Agaricus brasiliensis on the Axenic Method. Acta Scientiarum Agronomy, 32, 55-60. https://doi.org/10.4025/actasciagron.v32i1.5086

[9] Lattanzio, V., Lattanzio, V.M.T. and Cardinali, A. (1996) Role of Phenolics in the Resistance Mechanisms of Plants against Fungal Pathogens and Insects. In: Imperato, F., Ed., Phytochemistry. Advances in Research, Research Signpost, Kerala, 23-67.

[10] Osbourn, A.E. (1996) Preformed Antimicrobial Compounds and Plant Defense against Fungal Attack. Plant Cell, 8, 1821-1831. https://doi.org/10.2307/3870232

[11] Neupane, S., Thakur, V., Bhatta, B., Pathak, P., Gautam, B.B. and Aryal, L. (2018) Performance of Different Substrates on the Production of Oyster Mushroom (Pleurotus florida) at Gokuleshwor, Darchula. International Journal of Scientific and Research Publications, 8, 231-240. https://doi.org/10.29322/IJSRP.8.6.2018.p7832

[12] Nelson, D.L. and Cox, M.M. (2004) Nucleotides and Nucleic Acids. In: Principles of Biochemistry, 4th Edition, W. H. Freeman and Company, New York, 200, 278-300.

[13] Wang, G.S., Jae-Won, L., Zhu, J.Y. and Jeffries, T.W. (2011) Dilute Acid Pretreatment of Corncob for Efficient Sugar Production. Applied Biochemistry and Biotechnology, 163, 658-668. https://doi.org/10.1007/s12010-010-9071-4

[14] Sharma, S., Yadav, R.-K.P. and Pokhrel, C.P. (2013) Growth and Yield of Oyster Mushroom (Pleurotus ostreatus) on Different Substrates. Journal on New Biological Reports, 2, 3-8.

[15] Jongman, M., Khare, K.B. and Khonga, E.B. (2013) Effect of Different Grain Spawns and Substrate Sterilization Methods on Yield of Oyster Mushroom in Botswana. International Journal of Bioassays, 2, 1308-1311.

[16] Sławińska, A. and Kalbarczyk, J. (2011) Evaluation of Enzymatic Activity of Pleurotus ostreatus Regarding Stages of Mycelium Development. Acta Scientiarum Po- 
lonorum: Hortorum Cultus, 10, 195-202.

[17] Inyod, T., Sassanarakit, S., Payapanon, A. and Keawsompong, S. (2016) Selection of Macrocybe crassa Mushroom for Commercial Production. Agriculture and Natural Resources, 50, 186-191. https://doi.org/10.1016/j.anres.2016.06.006 